\title{
Definition of Substitute Family Care and Issues of the School Environment
}

\author{
Lukáš Stárek
}

Correspondence: Lukáš Stárek, Univerzita Jana Amose Komenského Praha s.r.o., IČ: 46358978 Roháčova 1148/63, 130 00 Praha 3, Praha 3, 13000, Czech Republic.

\author{
Received: July 7, $2020 \quad$ Accepted: August 2, $2020 \quad$ Online Published: August 3, 2020 \\ doi:10.11114/jets.v8i9.4954 URL: https://doi.org/10.11114/jets.v8i9.4954
}

\begin{abstract}
As part of the transformation of the care system for children at risk in the Czech Republic, alternative family care has a fundamental priority over the placement of children in institutional care. Nowadays, teachers increasingly encounter a child living in a foster family at school. The educational program reflects various situations in the life of children who preceded their placement in foster care. These specific life experiences prevent children from establishing successful relationships, respecting boundaries and successfully participating in their educational process.
\end{abstract}

Keywords: family, school, substitute family care

\section{Introduction}

When all the needs of the child are satisfied, then it is a good prerequisite for proper development and growth. Building a sense of security and a loving environment on the part of parents provides the basis for the child's stability and development. For some of us, these may be ordinary human needs, but some people and children do not have or have not experienced this "ordinariness". Unfortunately, we still come across parents who, for various reasons, cannot, do not want or have a lack of the skills to look after their children. These children miss out on solid family background, confidence, security, and love. It may even happen that a parent abandons their child. The reasons for this may vary for example, indifference, illness, psychological problems, lack of anchoring or personal instability. Such a parent or family cannot fulfil their parental roles, fulfil their parental responsibilities, and provide a favourable educational environment for the child. The emergence of this situation/fact is when substitute family care comes into play.

\section{Definition of Substitute Family Care}

Substitute family care is an umbrella term for all types of non-institutional childcare where a child is placed in, for various reasons, his/her biological parents cannot provide care (Nožírová, 2012). They are thus raised by persons other than their biological parents in an environment that is most similar to living in a "real" family.

The definition of substitute family care is not uniformed, although the meanings are similar. A uniformed indicator is always the legal/legislative framework that defines foster family care. The diversity of the authors' views (in the Czech Republic: Benešová, Bubleová, Dunovský, Dytrych, Matějček) is evident in the starting points of psychological or social aspects of substitute childcare.

Matejcek and Dytrych state "substitute family care can be defined as social measures in favour of a child whose parents cannot or do not want to provide care for, or for serious reasons, it is not desirable that they provide care" (Matějček and Dytrych, 1994, p. 166). The authors also add that this form of childcare is intended primarily to ensure the child's harmonious development, to enable the child to grow up in a family environment that satisfies his/her basic psychological needs and prepares him/her for suitable social inclusion.

Bubleová and Benešová (2001) define substitute family care in the following way: "substitute family care is a form of childcare where the child is brought up by 'substitute' parents in an environment that is most similar to life in a natural family. This mainly means adoption and foster care in this country “(Bubleová a Benešová 2001, s. 4).

Dunovský (1999, s. 227) explains that: "substitute family care means care for abandoned, orphaned children who for some reason lost their own family or did not find it at all, in a new family environment or a similarly organised small group resembling or approaching the family."

However, the diversity authors' definitions of substitute family care is more due to the use of the definition within the many and varied fields that address the topic of substitute family care. At the same time, it must be noted that all fields, 
including psychology, pedagogy, paediatrics, family education, counselling, etc., intertwine and try to address the problem competently from their unique perspective, albeit always in relation to other fields.

Current legislation, primarily Act No. 89/2012 Coll., The Civil Code; Act No. 359/1999 Coll., on Social and Legal Protection of Children, clearly states the principle of prioritising substitute family care over institutional care. The system is set up therefore if the child cannot stay in its family environment, substitute family care will be the next solution in line. "The new legislation aimed to create legal conditions for systematic work with families that will ensure that the child remains in a family or alternative family environment. The system is now more oriented to prevent child's risk and timely solutions. The rules for the activities of employees of the social and legal protection of children, especially at the level of municipalities with broader impact and responsibilities, have been amended. Municipalities should, after evaluating the situation, look for an optimal solution for each child individually within the framework of multidisciplinary cooperation and by using the network of services. Quality standards and binding procedures are now clearly set in the system. The quality standards apply both to the bodies of the social and legal protection of children and to persons authorised to exercise social and legal protection. Foster care is now carried out on a professional basis, and the conditions for providing care are set by a decision or agreement on the provision of foster care. The system of preparation and selection of foster parents has been unified, as well as the method of their material provision (including temporary foster care). A network of support and relief services is now available to foster parents. "(Asociace dítě a rodina, online, citace 2020-03-12)

\section{Substitute Family Care in Numbers Within the $\mathbf{C Z}$}

In the Czech Republic, over CZK 8 billion is spent annually on the care of vulnerable children from public budgets. Most of the funds continue to go to institutional education. The average cost per child in foster care is CZK 16,046 per month. This amount includes all foster care benefits as well as the state allowance for the provision of foster care, which is used to finance organizations providing professional support to foster families. In the case of placing a child in institutional care, the cost of care is significantly higher. The average cost per child placed in an institution exceeds CZK 40,000 per month. The stay of one child placed in orphanage amounts to CZK 32,000 per month. In April 2020, CZK 327.4 million was spent on foster care benefits, i.e. year-on-year by approx. CZK 3.2 million (by 1.0\%) more. (Ministry of Labour and Social Affairs, online, citace, 2020-05-22)

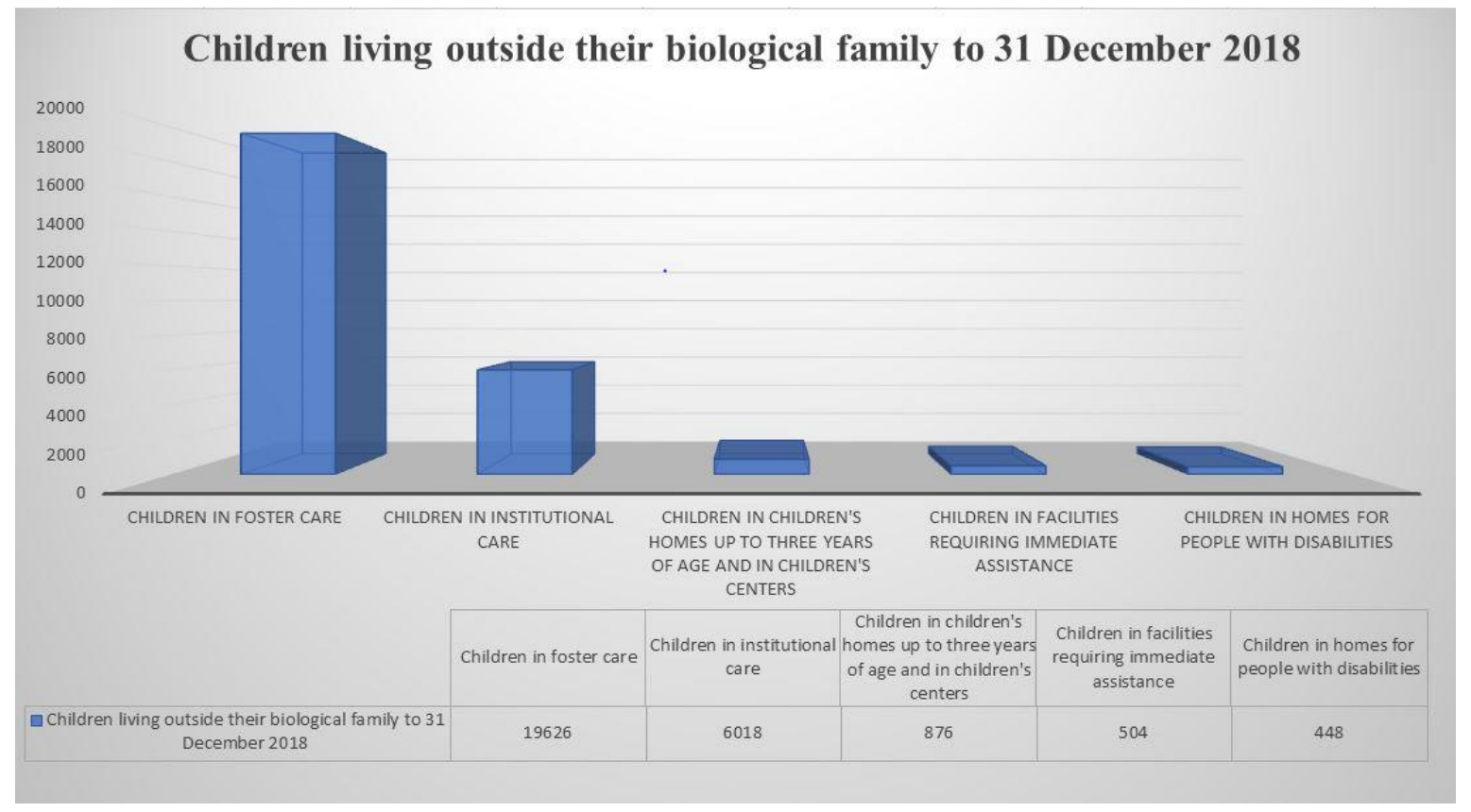

Figure 1. Number of children living outside their biological family; Ministry of Labour and Social Affairs, online, 2020-02-18 


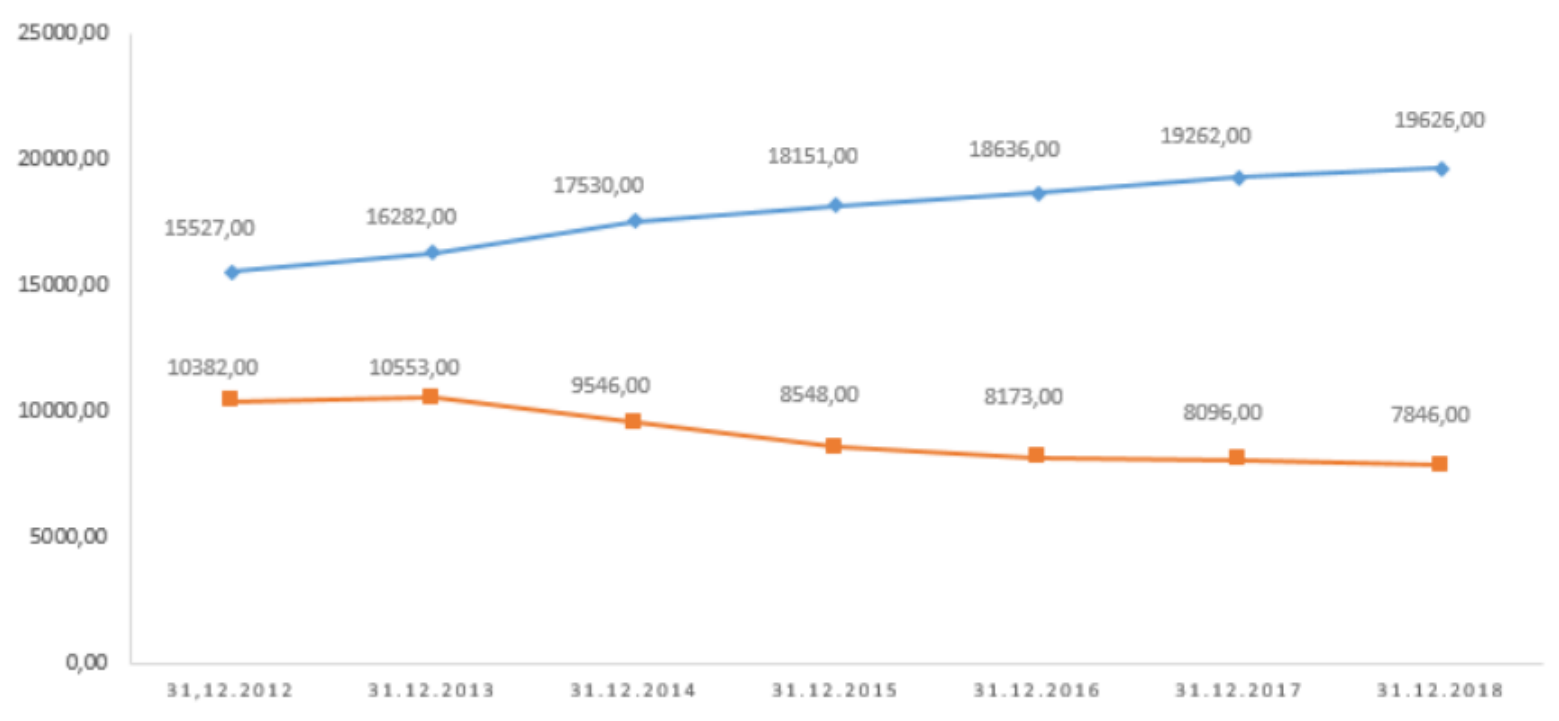

Figure 2. Number of children living in foster care and institutional care since 2012; Virtuální Knihovna Náhradní Rodinné Péče, online, 2020-05-11

The institutional facilities for children include children's homes, children's homes with a school, educational institutions, diagnostic institutes, children's homes for children under three years of age, infant institutions, facilities for children requiring immediate assistance, homes for children with disabilities.

At the end of 2018, 19626 children were placed in substitute family care. The growth of children in substitute family care is increasing every year. This fact indicates an attempt to place children in substitute family care rather than institutional care. The number of children living in institutions is decreasing, but still very slowly. In comparison, at the end of 2018, a total of 7846 lived in institutional facilities.

\section{There are Different Forms of Substitute Family Care in the Czech Republic}

\subsection{Placing a Child in the Care of a Natural Person Other Than a Parent}

Legislative definition - Act No. 89/2012 Coll. Civil Code, Sec. 953 - Sec. 957.

"If neither the parent nor the guardian can personally care for the child, the court may place the child in the personal care of another person... The decision to place the child in custody must be in accordance with the child's interests. Placing a child in the caregiver's care does not replace foster care, pre-foster care or care that must precede adoption. It takes precedence over the care of a child in institutional care.” Act No. 89/2012 Coll. Civil Code, Sec. 953

The court decision always defines the scope of rights and obligations in relation to the child. Most often is the provision of care for the child and its representation in ordinary matters. When choosing the appropriate caregiver, the court takes into account the family relatives of the child. Furthermore, the guarantee of proper upbringing must be ensured, and the caregiver must agree to the custody of the child.

The spouses can also become caregivers. If a married couple who have custody of the child divorce, the rights and obligations of the spouses to the child must be adjusted. If during the divorce, the court intends to place the child in the custody of one spouse, it may do only with the consent of the other. In the event of the death of one of the spouses, the child remains in the custody of the other spouse.

Unless the court decides otherwise, the child's parents remain liable for parental responsibility, continue to be the legal guardians of the child, and maintain an obligation towards the child. The carers have the right to maintenance from the child's parents, which they can enforce. The amount of maintenance is determined by a court decision. The maintenance should be in accordance with the child's needs and interests.

The caregiver is not entitled to foster care benefits or other special benefits. 


\subsection{Types of Adoption}

Legislative definition - Act No. 89/2012 Coll. Civil Code, Sec. 794 - Sec. 854.

The adoption means accepting a non-family member as one's own. "The prerequisite for the adoption is a relationship between the adoptive parent and the adoptee as there is between a parent and a child, or that there are at least the foundations of such a relationship. The adoption of a minor must be in accordance with his or her interests."

In the case of adoption, a relationship exists in legal terms between the adoptive parent and the adopted child identical to the one between biological parents and their children. This changes the ties of the child with regards to his or her original parents, and all rights and obligations in relation to the original family, as determined by a court decision, are nullified.

The adoptive parents are registered on the child's birth certificate and must assume complete parental responsibility. Therefore, the adoptive parents are the legal representatives of the child. The child adopts the surname of his/her adoptive parents. By the start of schooling at the latest, the child should be informed of the fact that he or she is adopted. This is a legal obligation on the part of the adoptive parents.

The adoption is decided by the court. A child must be in the care of a future adoptive parent for at least six months at the expense of the said parent.

An adoption cannot be revoked three years after the adoption decision of the court. An adult can also be adopted unless it is a violation of good morals. There is no special oversight or supervision by the state in relation to adoptive parents.

\subsection{International Adoption}

International adoption means the adoption of a child abroad or from abroad. If it is not possible to find a substitute family for the child in his or her country of origin, international adoption is a possible solution. The international adoption is governed, inter alia, by the Convention on the Protection of Children and Cooperation in International Adoption - the so-called Hague Convention on the Protection of Children, which defines the functionality of an authority/body in this field. The Office for International Legal Protection of Children, which is based in Brno, operates within the Czech Republic.

\subsection{Foster Care}

Legislative definition - Act No. 89/2012 Coll. Civil Code, Sec. 958-970; Act No. 359/1999 Coll., on Social-legal Protection of Children.

"If neither the parent nor the guardian can personally care for the child, the court may place the child in the care of a foster parent. Foster care takes precedence over placing a child in institutional care." (Act No. 89/2012 Coll. Civil Code, Sec. 958)

Foster care is applied to children who cannot be raised by their parents, but ties are maintained. This fact can be linked not only to parents but also to other relatives - e.g. siblings or grandparents. One of the duties of a foster parent is precisely to allow parents to contact the child, to develop a certain sense of belonging and to develop their mutual relations. The main aim of foster care is to provide care for the child and its upbringing in a family environment.

The foster parent has the right to represent the child and to manage his/her affairs only in normal matters and has no maintenance obligation. The foster parent may be an individual or a married couple. There is no family relationship between the foster parent and the child. Thus, the biological parent, who has parental responsibility for the child, remains the legal representative.

The court decides on foster care for the period that the obstacle preventing the child's parents from personally caring for $\mathrm{him} /$ her exists. Some children have been in the care of foster parents for several years; others remain in this form of care until they reach the age of majority. Foster care expires at the latest when the child acquires full legal capacity, otherwise by the child's age of majority.

Foster care is supported by the state in terms of foster care benefits, which are to ensure the basic material security of the child and at the same time take into account the difficulty of this care by providing foster care payments.

"Foster care benefits include the Child Benefit Allowance; Foster Care Allowance; Foster Parent Payment; Acceptance Allowance; Personal Motor Vehicle Purchase Allowance." (Ministry of Labour and Social Affairs of the Czech Republic, online, cit. 2020-06-12)

The process of mediation and custody of a child is defined under Act No. 359/1999 Coll., On Social and Legal Protection of Children, which includes, inter alia, the process of mediation and custody of a child:

1. The submission of an application for inclusion in the register of applicants eligible to become foster parents to the 
municipal office of a municipality with broader authority. Where the applicant has his/her permanent residence (in the case of spouses at the permanent residence of one of them). The application form can be obtained directly from the office or downloaded from the MoLSA website.

2. The assessment of applicants by the municipal office with broader authority: The municipality will carry out a social investigation into the family of the applicants in the place of their actual residence. After gathering the necessary documents (report on the state of health, property conditions, etc.), which is a prescribed part of the application, the municipal authority will forward the application to the relevant regional authority. It shall attach its opinion to the application.

3. The assessment of applicants by the regional authority: The regional authority will ensure the psychological examination of the applicants and the assessment of their application by an assessment doctor. At the same time, it will include applicants in preparatory courses for the admission of a child to foster care. The professional assessment of applicants focuses primarily on the characteristics of their personality, their psychological and health condition concerning the best assumptions for raising a child. It also assesses the applicant's motivation that led to their application for custody of a child, the quality of their relationships and the stability of their family environment. Among other things, the attitude of other family members in accepting a child in this form of foster care is also examined. The expert assessment also includes an assessment of the preparation for the adoption of a child into foster care.

4. The decision on inclusion or non-inclusion in the register: According to these findings of a previous expert assessment, the regional authority will issue an administrative decision on the inclusion or non-inclusion of applicants in its foster parents register for mediation of foster family care. If the applicant disagrees with the outcome of the decision, there is a possibility of appeal.

5. Choosing a family for a child: The regional authority also keeps a record of children whose situation requires foster care. The choice of the family for a particular child depends on the needs of the child and the ability of future foster parents to meet those needs.

6. Establishing contact with the child: The selected family is approached by the regional authority, acquainted with the child's situation and documentation in detail, and is subsequently provided with personal contact.

(Foster Care Centre, Society, online, citation 2020-04-15)

\subsection{Temporary Foster Care}

Legislative definition - Act No. 89/2012 Coll. Civil Code, Sec. 958; Act No. 359/1999 Coll., on Social-legal Protection of Children. The court may place the child in foster care for a temporary period. (Act No. 89/2012 Coll. Civil Code, Sec. 958)

The aim of temporary foster care is primarily to provide time for biological parents to adjust their circumstances, which would then allow the child to be placed back into care. This time can also be used to find a different, more suitable family for the child.

Therefore, it is primarily an emergency measure and only temporary, with the maximum length of stay being one year at the most. This option allows the child to avoid being placed in an institution.

Temporary foster parents are financially supported by foster care payments (Child Benefit Allowance; Foster Care Allowance; Foster Parent Payment; Acceptance Allowance; Personal Motor Vehicle Purchase Allowance) and are provided with expert assistance and supported from accompanying organisations or the Department of Social and Legal Protection of Children of a municipality.

\subsection{Guardianship}

Legislative definition - Act No. 89/2012 Coll. Civil Code, Sec. 928 - Sec. 942. "If there is no parent who has full parental responsibility for the child, the court will appoint a guardian to the child. The guardian has, in principle, all the duties and rights as a parent of the child but has no maintenance obligation regarding the child. With regards to the guardian's person or the circumstances of the child, as well as to the reason for which the parents do not have all the duties and rights, the scope of the guardian's duties and rights may in exceptional cases be different." (Act No. 89/2012 Coll. Civil Code, Sec. 928)

The court will appoint a guardian to the child if: the child's parents have died; the parents have been denied parental responsibility; their parental responsibility has been suspended; they do not have full legal capacity (and therefore do not possess parental responsibility). No legal relationship between the guardian and the child exists as it is between the parent and the child.

If the guardian personally cares of the child, he/she is entitled to foster care payments (Child Benefit Allowance; Foster 
Care Allowance; Foster Pa-rent Payment; Acceptance Allowance; Personal Motor Vehicle Purchase Allowance).

The guardian is directly responsible to the court with local jurisdiction and is subject to regular supervision. The guardian reports to the court about the child in his/her care, usually at annual intervals. If the guardian wants to make a legal decision on a crucial matter relating to the child, the court's approval is required.

\section{The History of Substitute Family Care in the Czech Republic}

Within the historical legislative definition, the pivotal edition of the Imperial Law of the Home no. 105, of the Imperial Code from 1863 is crucial. This law was subsequently followed by the Provincial Poor Act for the Czechs, No. 59, the Provincial Code. Both legislative sources are one of the first measures introduced by the public administration for the benefit of the poor and govern poor relief relatively broadly (medical treatment of the poor, nutrition and education of children from poor municipalities, facilities for reforming neglected youth). Poor relief for children provided compensation for absent parents, either in special institutions (orphanages) or in foster care. The family was the preferred form. The assumption was like today's thinking, i.e. the best environment for raising a child is a good family that ensures the child's physical and moral development. This care was provided by home communities. However this arrangement, had its shortcomings, especially the insufficient funding from municipalities.

A partial improvement occurred at the beginning of the 20th century based on Act No. 62/1901 of the Imperial Law, which laid the foundation for the establishment of the so-called land orphan funds. The provincial orphan funds have appropriately used the surpluses from the orphanage's coffers to provide for and raise orphaned and abandoned children. Along with poor relief, there were also voluntary organisations and institutions for children and youth.

Since 1904, the so-called "district commissions for youth care" started to be established, bringing together volunteers who helped orphaned children. After the establishment of the independent Czechoslovak Republic in 1918, the district commission for youth care was declared as the organisational unit for all voluntary youth care. An important document to be mentioned in connection with the development of district care was the Government Decree No. 20/1930 Coll., on Collective Guardianship, which was the statutory instrument of the Act No. 256/1921 Coll. According to these standards, if a suitable guardian was not found, the court entrusted the guardianship to the district commission for youth care. Since 1924, the Central Social Committee and the Central Social Office has operated in Prague.

After the war, the tasks of youth care were transferred to the district and provincial national committees in 1947. Act No. 69/1952 Coll., on the Social and Legal Protection of Youth brought about a substantial intervention in the protection of children. Socio-legal protection was limited to providing institutional guardianship and custody of children not in the care of their parents. From the time of poor relief until now, substitute family care has been given priority in cases of need to care for children outside their own family.

The Family Act of 1963 opened the way to a series of experiments, in particular the so-called "large families", whether living individually or concentrated in children's villages. Act No. 50/1973 Coll., on Foster Care, completely covered substitute family care at that time.

Before the Act No. 359/1999 Coll., on the Social and Legal Protection of Children came into effect, the activities of state bodies focused on child protection were regulated by the Family Act and, from the point of view of defining the scope of power of individual institutions and social security regulations. However, this status did not meet the needs of children, in particular the protection of children in developing civil society was not sufficiently ensured. The key changes in the area of family law occurred at the end of the 1990s, especially in connection with the adoption of Act No. 91/1998 Coll., which substantially amends and supplements the Act on Family Act No. 94/1963 Coll., as amended. At that time, the foster care legislation was incorporated into the Family Act. The form of substitute family care is preferred to institutional care. Furthermore, this led to the acceptance of the aforementioned Act on Social and Legal Protection of Children being adopted, which can be understood as the basis of public protection of children. (Matějček, 1999)

The 21st century also brings changes. Since 2003, substitute family care in the sense of their mediation of substitute family care has been provided by regional authorities, which maintain registers of suitable foster parents and of children who can be placed in substitute family care. The tasks are also carried out at the municipal level by municipal authorities with broader powers. This is where the individual applicants for foster family care first learn relevant information. Municipalities also provide all documents for the operation of the regional authority.

\section{The School Environment and a Child in Foster Care}

The differences between a child in a "classic" family and a child in a foster family are caused due to two main reasons. The first reason is a child's unique personality and born attribute. However, the second and more significant reason is parents' original upbringing and quality of their mindset. Almost every child, placed in foster care had experienced the substitutional care, Šulová (2010) states that in development of a child a crucial negative role-plays social disadvantages, 
therefore the social aspects are more significant in the development of a child than the biological aspects. "In quality psycho-social conditions the children with many biological risks have a chance to experience "normal" development. However, the psycho-social conditions can have a negative effect as well (Šulová, 2010, s. 28). Almost every psychological developmental theory claim that for the normal development of a child is crucial to experience fulfilling interpersonal relationships, and the importance of early social and emotional experience. All of those together, make an important package which allows a child to grow up in an ordinary person. The environment and style of care, which a child experience from the begging of its life, have a significant impact on all developmental areas of a child and future success. Mainly in a child's early years, it is crucial to experience a close relationship and individual care. Many significant studies have shown that children with good health conditions, who have experience substitutional care in their early years, have later problems in school, job and relationships.

For children in foster care, the start of mandatory schooling can be more difficult than for their peers, who have lived in their family. It is recommended by teachers and social workers to begin with mandatory schooling at the moment when a child is acclimated in a foster family and the circle of trust is build (Kovaríík et al., 2004). According to Zezulová (2012) children who have experienced substitutional deprivation and who have not a specific need, can visit "normal" schools and fit in its collectives. However, the problems arise at the moment when children in foster care are seemed by teachers as "usual" children without the need for individual care (Zezulová, 2012). It is proved that children who have not had a chance to make a close relationship with their primary career are usually slower in development of language and that they have smaller vocabulary knowledge. Also, their development of cognitive function is slower. The school performance of this children is not corresponding with their real intellect, therefore the problems with lower self-confidence, problems with relationships (mainly with peers and authorities) are seen often (Vrtbovská, 2010).

According to Holá et al. (2007), the process of cooperation with schools is hard because teachers do not understand to foster care families and cannot cope with specific needs of those children and families. The school is at begging helpful and friendly, whereas when some problems come up the positive attitude is over. The children from foster families often need extra help and quality work in school and at home as well. From this point of view, there is a huge gap between teachers and foster families. The teachers should be able to cope with the specific needs of each child and they should be able to modify their teaching activities so the activities will suit everyone. Often children in foster families have tendencies in their pubescent age take control of their life, they are trying to find the boundaries, breaking rules which used to work. Like each child, they also try some drugs, lie, and often they experience anorexia, bulimia etc. Also, around this age for foster children could be problematic to starts new relationships, therefore they could have problems with missing school or experience depression. Another significant problem which can arise around this age is finding of own identity, which is called genealogic chaos. The genealogic chaos is a feeling of isolation from genetic family, culture, ethnicity, religion or race. Those children have problems to find something similar to their parents, and often children from diverse ethnicity experience fear from diversity. Unfortunately, children often try to find their way from this situation which often leads to a non-conventional solution such as: finding problematic friends, using drugs, getting pregnant. All these solutions should fill the emptiness which these children can experience because they feel like they are missing from their personality.

The wider society is not very aware of surrogate family care, so it often responds disproportionately or not at all takes into account that this care is something special. Children in foster care, for example, encounters many unpleasant situations at school. In the first or Civics are given the task of bringing photographs of families and looking for visual similarities between each other and family members or create pedigrees. These tasks are for children in a surrogate family very stressful. Their otherness stands out in them, and they even sometimes meet even with the teacher's misunderstanding when they do not want / cannot perform such a sensitive task.

The school co-determines the further development of the schoolboy, contributes to the development of his abilities, skills and personal qualities. Teachers evaluate the child's performance and behaviour in a certain way, and this evaluation is also important for his future social position. The school contributes to socialization the child in a different way than the family, the child gains a different experience than the one he gained home. It stimulates the emergence of new needs (eg performance needs) and the adoption of new values (eg success). For schoolchildren, good performance and gain are often a significant value acceptable positions in the classroom. Successful adaptation to school is associated with the need for more independence and acceptance of responsibility for one's actions (whether in the performance of tasks or behaviour towards other children). Starting school can be understood as an important phase in the process of detachment from the family when its influence is gradually replaced by action other social groups.

The results in the first years of school lead to the definition of a certain expectation in regards to benefit and behaviour that would be achievable for the child and acceptable to adults. It is a time of stabilizing goals when it is clear to everyone what they can demand from the child. If If a child comes to a foster family only during school age, it can be improved later, because only now it has acceptable conditions for its application. E.g. only now he goes to school 
regularly and prepares for classes, he has a chance to fill in the missing one's knowledge and skills, sometimes it is only at this time that minor sensory disorders are discovered no one has solved it yet. (Vágnerová, 2012)

School to a large extent influences the formation of the child's self-concept, his self-esteem and self-esteem, but also expectations of future successes or failures. One way the schoolboy confirms his value by meeting the requirements of the teacher. The success rate of their mastery is reflected in his attitude to school and education. This attitude can with certain fluctuations persist into adulthood. If a child fails at school, he or she can seek satisfaction elsewhere, sometimes in opposition to it. Failure happens once for the causes of problematic behaviour by which the child compensates for his failure. That's right it is also used for many children living in a foster family. Sufficient information about the possibilities and limits of the adopted child will usually contribute to calm the situation not only in the family but also at school. If teachers know why a child cannot master the curriculum to a normal extent, they are willing to approach it individually and not to require more than they can.

When communicating with the school, foster parents could have problems with not being legal child representatives. When enrolling a child in school, it is appropriate to document the court decision on entrustment the child to foster care. The school staff member saves a copy of the decision in the documentation about the child, and the school then communicates with the foster parents instead of the child's parents.

If the school refuses to communicate with foster parents in this way, the foster parent has the opportunity to convert to your social worker, who should help obtain the consent of the child's parents. If it is difficult to obtain such consent, the social worker will help to write a proposal for a provision a guardian who consents to the school enrollment. However, only for this action. However, the obligation of the legal representative's consent is also on other documents - on the application to the school group, to swimming training, to the school in nature and other events organized by the school. (Striová, 2015)

A similar situation can occur when communicating with a pedagogical-psychological counselling centre or a special pedagogical centre, where foster parents often turn for help and cooperation. By law, the foster parent is to represent the child in common situations. In current practice, this it was often the case that the foster parents represented the child in everything unless the other party said that they have no right to do so. It was important not to sign as legal in such a situation representative, but add the name foster parent to his signature.

In some cases, foster parents have in the court decision to entrust the child to foster care states that they are empowered to choose school facilities. Even so, foster parents should inform the child's parents about the choice of school. If they are not in contact with them, just write a letter or message and leave it with the child's social worker in case the parents later expressed interest in information about the child. The form of the letter could be similar to how the guardians process the annual report on the child in court.

A questionnaire survey among primary school teachers shows that a sensitive topic is usually a photo from an early age childhood. Either the foster parents do not have it at all, or it is so rare for them that they may refuse to post it on the notice board in the classroom. Another sensitive topic is pedigree. Most children automatically build the family tree of their surrogate family or something mixes spare and biological family. Such a task is sometimes the impetus for organizing a discussion about surrogate family care in the classroom either by the child himself or by a foster parent to talk about alternative family care. The pedigree is very sensitive a topic for children living in foster care of grandparents, especially when the father is unknown (Talpa, 2019).

\section{Professional Employment of Substitute Family Care Workers}

Professional employment is subject to valid legislation which shows that the graduate is a qualified educational worker or social worker.

Competencies: professional fields; social/special education; diagnostic; interventional; communication; personality cultivating.

\subsection{Work Activities of a Foster Family Worker}

- works with children eligible for foster care and with foster parent applicants;

- provides complete documentation necessary for the mediation of foster family care;

- accepts applications for foster care, provides information on the process of including applicants in the register of persons eligible to become foster parents. As part of this activity, it carries out a detailed social survey in families, provides counselling, and seeks persons suitable for becoming foster parents;

- monitors the development of children placed in foster families, cooperates with foster parents, biological parents, provides social and legal counselling, targeted assistance to all; 
- represents children as guardians before courts, police, notaries and other institutions, protecting the interest of minors;

- cooperates with foster parents and guardians;

- oversees the proper development of children placed in foster or guardian care;

- $\quad$ knows current legislation and applies it in practice;

- uses his/her knowledge and skills for the benefit of the client/child;

- provides social and legal counselling in connection with exercising social and legal protection of children;

- $\quad$ provides social counselling to children and parents in solving their family, personal problems and acute crises mediates the assistance of professional counselling and health care workplaces and other professional facilities;

- cooperates with institutions that have entered into a foster care agreement with carers or registered persons in the administrative district of the social-le-gal protection body;

- the locally competent regional authority makes notifications of children eligible for foster care;

- $\quad$ acts preventively and participates in preventive measures ensured by the BSLPC;

- $\quad$ provides field social work;

- member of a multidisciplinary team;

- $\quad$ observes the ethical principles of the social worker;...

\subsection{Possible Professional Employment}

- $\quad$ authority for the social and legal protection of children - MoLSA CR, regions and municipalities with extended powers;

- non-governmental non-profit organisations focused on support, assistance and counselling in the field of foster family care;

- foster care centres;

- foster family programmes;

- $\quad$ help centre for children at risk...

\section{In Conclusion}

The above text summarized the system of substitute family care in the Czech Republic and focused on one of the major problems. The thematic area is becoming a school, not only from the point of view of education, but also from the point of view of social interaction. An environment that is ground-breaking for the child's development and depends not only on the teacher, the students, but society as such, what position they take. Children in substitute care have a much-increased rate of psychosocial problems but also, they come from high risk backgrounds. Risk and protective influences include genetic factors; physical traumata; preadmission psychosocial experiences; experiences 'in care', and experiences after leaving care. Interplay among these is usual.

The foster care is not phenomena of this age, the priority has always been and always will be a child. The system is focused on unification of the foster care system, support and help for endangered families, support of professional foster care and reducing the number of long-term placed children in substitutional care. Therefore, this topic is now very accurate and mainly in relation to actual changes in care of a child in a danger. Nowadays, the support in focused on care givers and the changes should bring more focus on a child and its development and integration in foster family.

In many categories which can formed a child, the main one is school. The school which shapes a child/a learner, which should provide sufficient developmental support including development in knowledge and skills. Also, the learner should be shaped in benefit of society and in benefit of its own. This positive attitude can work if the teacher is acknowledged about the problematic of foster care and if the teacher can work with possible issues which may arise during the communication with foster care parents. The individuality of each child needs to be acknowledged by each teacher, and of this will happen then the class environment can be built on trust and confidence.

\section{References}

Act No. 359/1999 Coll., on the Social-Legal Protection of Children. In: Collection of Laws of the Czech Republic. ISSN 1801-8688.

Act No. 89/2012 Coll. Civil Code, [In:] Collection of Laws of the Czech Republic. ISSN 1805-9589.

Asociace Dítě a Rodina. Právní úprava náhradní rodinné péče v České republice. [online]. [cit. 2020-03-12]. Dostupné z: 
https://www.ditearodina.cz/images/soubory/pravni-up-rava-nahradni-rodinne-pece-v-cr.pdf

Barvíková, J. (2015). Anketa k pěstounské péči. Fórum sociální politiky, 9(5), 26-28.

Bubleová, V. et al. (2011). Základní informace o náhradní rodinné péči. Praha: Středisko náhradní rodinné péče o.s.. ISBN 978-80-87455-01-2.

Bubleová, V., \& Benešová, L. (2001). Hledáme nové rodiče. Praha: Středisko náhradní rodinné péče. ISBN 80-239-1355-7.

Bubleová, V., \& Vránová, L., \& Vávrová, A., \& Frantíková, J. (2011). Základní informace o náhradní rodinné péči. Praha: Středisko náhradní rodinné péče o. s. ISBN 978-80-87455-01-2.

Charter of Fundamental Rights and Freedoms, [In:] Collection of Laws of the Czech Republic. ISSN 1211-1244.

Daly, A., \& Ruxton, S., \& Schuurman, M. (2016). Challenges to children's rights today: what do children think? Strasbourg: Council of Europe.

Davies, M. (2012). Social Work with Children and Families. New York: Palgrave Macmillan. ISBN 978-0-230-29385-4. https://doi.org/10.1007/978-1-137-00567-0

Dunovský, J. (1999). Sociální pediatrie vybrané kapitoly. Praha: Grada Publishing. ISBN 80-7169-254.

Härkönen, J., \& Bernardi, F., \& Boertien, D. (2017). Family Dynamics and Child Outcomes: An Overview of Research and Open Questions. European Journal of Population, 33(2), 163-184. https://doi.org/10.1007/s10680-017-9424-6

Holá B. et al.. (2007). Pěstouni mají právo na služby. Praha: Rozum a cit.

Kolektiv autorů, (2018). Dobrý pěstoun: náhradní rodinná péče v ČR. Tábor: Asociace poskytovatelů sociálních služeb ČR. ISBN 978-80-907053-2-6.

Kovařík, J. (2004). Náhradní rodinná péče v praxi. Praha: Portál, 2004. ISBN 80-717-8957-7.

Matějček, Z. (1999). Náhradní rodinná péče: průvodce pro odborníky, osvojitele a pěstouny. Praha: Portál. ISBN 80-7178-304-8.

Matějček, Z., \& Dytrych, Z. (1994). Děti, rodina a stres. Praha: Galén. ISBN 80-85824-06-X.

Ministerstvo Práce a Sociálních Věcí ČR. /Ministry of Labour and Social Affairs of the Czech Republic. Dávky pěstounské péče. [online]. [cit. 2020-06-12]. Dostupné z: https://portal.mpsv.cz/soc/dpp

Nožířrová, J. (2012). Náhradní rodinná péče. Praha: Linde Praha. ISBN 978-80-86131-91-7.

Ptáček, R. (2011). Vývoj dětí v náhradních formách péče. Praha: Ministerstvo práce a sociálních věcí ČR. ISBN 978-80-7421-040-2.

Šmajdová Búšová, K., \& Kučera, M. (2015). Profesionální rodičovství: etnografická studie. Praha: Univerzita Karlova v Praze, nakladatelství Karolinum. ISBN 978-80-246-2779-3.

Středisko Náhradní Rodinné Péče, Spolek./Foster Care Centre, Society. Proces zprostředkování a svěření dítěte do pěstounské péče. [online]. [cit. 2020-04-15]. Dostupné z: https://www.nahradnirodina.cz/

Striová, M. (2015). Nejčastější praktické problémy při výkonu náhradní rodinné péče. In.: Kolektiv autorů (2015). Sborník príspěvků k aktuálním tématům náhradní rodinné péče. Praha: Ministerstvo práce a sociálních věcí ČR. ISBN 978-80-7421-103-4.

Šulová, L. (2010). Raný psychický vývoj ditěte. Praha: Karolinum, 2010. ISBN 978-802-4618-203.

Talpa, L. (2019). Metodika realizace besed na základnich a středních školách k tématu náhradní rodinné péče. Projekt Systémový rozvoj a podpora nástrojů sociálně-právní ochrany dětí Ministerstvo práce a sociálních věcí.

Trnková, L. (2018). Náhradni péče o dítě. Praha: Wolters Kluwer. ISBN 978-80-7552-864-3.

Vágnerová, M., M. (2012). Psychický vývoj dítěte v náhradní rodinné péči. Praha: Středisko náhradní rodinné péče o. s.. ISBN 978-80-87455-14-2.

Vavrečková, V., Tichá, M., \& Ondrúšová, Z. (2017). Substitute Child Care as a Current Problem of Social Care in the Czech Republic. Danube: Law Economics and Social Issues Review, 8(4), 237-248.

Vecchiato, T., \& Canali, C. (2013). Foster Care In Europe: What Do We Know About Outcomes And Evidence? Padova: Fondazione Zancan. 
Vecchiato, T., Maluccio, A. N., \& Canali, C. (2002). Evaluation in Child and Family Services: Comparative Client and Program Perspectives. New York: Aldine de Gruyter. ISBN 0-202-30722-0.

Virtuální Knihovna Náhradní Rodinné Péče. Počet dětí žijících mimo svou biologickou rodinu. [online]. [cit. 2020-05-11]. Dostupné http:/www.knihovnanrp.cz/nahradni-rodin-na-pece/aktualni-statistiky/pocet-deti-zijicich-mimo-svou-biologickourodinu/

Vrtbovská, P. (2010). O ztraceném ditěti a cestě do bezpeči. Praha: Natama, 2010. ISBN 978-80-86620-20-6.

Zezulová, D. (2012). Pěstounská péče a adopce. Praha: Portál, 2012. ISBN 978-802-6200-659.

\section{Copyrights}

Copyright for this article is retained by the author(s), with first publication rights granted to the journal.

This is an open-access article distributed under the terms and conditions of the Creative Commons Attribution license which permits unrestricted use, distribution, and reproduction in any medium, provided the original work is properly cited. 